\title{
Identifikasi Aves di Kawasan Taman Nasional Gunung Merbabu Sebagai Bahan Pembuatan Multimedia Interaktif Biologi SMA
}

\author{
Dhesti Nurul Fadhillah \\ Program Studi Pendidikan Biologi, Universitas Veteran Bangun Nusantara Sukoharjo \\ Alamat email koresponden: desti.yoshioka265@gmail.com
}

\begin{abstract}
The purpose of this study is To determine the types of Birds (Aves) which can be used for the preparation of the learning media in the form of Interactive Multimedia Area of the National Park of Merbabu Mountain, Selo district, Boyolali Regency, The form of this research is $R n D$ interactive multimedia, research Methods using point count method by applying random sampling in the taking of the shooting point. Data collection with the point count through the 4 replications. Large population is the entire Aves in the Area of Merbabu Mountain National Park.Results and conclusion the types of Aves found in the Area of Merbabu Mountain National Park as many as 12 Family 17 species and 156 individuals.Assessment of the third expert stated that the learning media in the form of interactive multimedia is Very Feasible to used as media of learning are valid. The application of learning media in the classroom by utilizing interactive multimedia as a teaching material at the time of learning according to the material or KD that have been written on the syllabus.
\end{abstract}

Keywords: identification aves, interactive multimedia, merbabu mountain national park.

\section{PENDAHULUAN}

Era pengetahuan abad 21 dicirikan dengan adanya pertautan dalam dunia ilmu pengetahuan secara komprehensif. Era global serta pengintegrasian teknologi dalam pendidikan, turut mempercepat terjadinya senergi pengetahuan lintas bidang ilmu. Oleh karenanya sains menjadi sangat penting (Sudarisman, 2015). Salah satu rumpun ilmu Sains adalah biologi yang memiliki karakteristik khusus yaitu mempelajari fenomena alam yang faktual (factual), baik berupa kenyataan (reality) atau kejadian (event) dan hubungan sebab akibatnya. Ada dua hal berkaitan yang tidak terpisahkan dengan biologi, yaitu biologi sebagai produk, pengetahuan biologi yang berupa pengetahuan faktual, konseptual, prosedural, dan metakognitif, biologi sebagai proses, yaitu kerja ilmiah (Laila dan Hindun, 2017;2).
Berdasarkan hasil wawancara dari beberapa sekolah di Kabupaten Boyolali antara lain di SMA N 1 Cepogo, SMA N II Boyolali dan SMA BK II Boyolali, guru mata pelajaran biologi SMA tersebut rata-rata mengatakan bahwa kesulitan siswa memahami materi dunia hewan dikarenakan banyaknya konten materi yang diajarkan dan saat pembelajaran hanya mengandalkan buku teks yang bersifat verbal. Selain itu nilai ketuntasan siswa yang berhasil masih rendah. Nilai ketuntasan siswa pada ulangan harian materi Keanekaragaman di SMA Negeri 1 Cepogo untuk MIPA 1 hanya mencapai 53,125\% (17 tuntas dari 32 siswa) dan MIPA 2 hanya 22,22\% (8 tuntas dari 36 siswa). Untuk nilai ketuntasan di sekolah lain yaitu di SMA Negeri II Boyolali dan SMA BK II Boyolali tidak jauh berbeda. Nilai ketuntasan SMA Negeri II Boyolali untuk kelas MIPA yaitu 43,75\% (14 tuntas dari 32 siswa) dan SMA BK II Boyolali masing-masing 38,89\% 
(14 tuntas dari 36 siswa) untuk MIPA 1 dan 40\% (12 tuntas dari 30 siswa) untuk MIPA 2. Kriteria Ketuntasan Minimal (KKM) yang ditetapkan pada materi Keanekaragaman hayati yaitu 65 di SMA N 1 Cepogo, 6,6 di SMA N II Boyolali, dan 70 di SMA BK II Boyolali. berdasarkan wawancara dengan bp Samsudin di SMA Negeri I Cepogo, diketahui bahwa di SMA tersebut belum pernah menerapkan pembelajaran di kelas dengan menggunakan media interaktif saat melakukan proses belajar mengajar materi keanekaragaman hayati pada kelas Aves, padahal penggunaan media (salah satunya multimedia interaktif) pada materi ini sangat di perlukan.

Penggunaan media yang tepat dan sesuai dengan era global saat ini diharapkan dapat mempercepat perubahan ilmu pengetahuan biologi, salah satunya pada ranah kognitif. Multimedia interaktif adalah salah satu media pembelajaran yang dapat digunakan sebagai media pendidikan di era 21. Multimedia merupakan perpaduan antara berbagai media yang berupa gambar, teks, sound, video dan interaksi yang dikemas menjadi file digital (IT), sedangkan pengertian interaktif yaitu terkait dengan komunikasi dua arah atau lebih dari komponen-komponen komunikasi (Munir, 2012;110).

Data atau bahan untuk pembuatan multimedia interaktif ini salah satunya adalah hasil penelitian yang akan dilakukan di Kawasan Taman Nasional Gunung Merbabu.

Taman Nasional merupakan kawasan pelestarian alam yang mempunyai ekosistem asli, dikelola dengan sistem zonasi yang dimanfaatkan untuk tujuan penelitian, ilmu pengetahuan, pendidikan, menunjang budaya, pariwisata, dan rekreasi (UU RI No. 5 Tahun 1990). Salah satu taman nasional di Indonesia, khususnya di Jawa Tengah adalah Taman Nasional Gunung Merbabu (TNGMB). TNGMB merupakan taman nasional yang tergolong ke dalam tipe hutan hujan tropis pegunungan (tropical mountain rain forest) (Balai TNGMB, 2017). TNGMB memiliki total luas 5.820,49 hektar yang menjadi habitat bagi 70 jenis burung (Balai TNGGP, 2017). Kawasan ini menjadi tempat hidup bagi beberapa jenis burung endemik di Jawa, diantaranya Elang Jawa, Puyuhgonggong Jawa, Celepuk Jawa, Walet gunung, Luntur gunung, Takur endemik Jawa, Tesia Jawa, Kipasan ekor-merah, Opior Jawa, hingga Kenari Melayu (MacKinnon dkk., 2010).

Hasil penelitian ini di harapkan dapat di gunakan sebagai salah satu media alternatif pembelajaran biologi di SMA kelas $\mathrm{X}$ berbagai tingkat keanekaragaman hayati dengan memanfaatkan Taman Nasional.

K.D. 3.2 Menganalisis data hasil observasi tentang berbagai tingkat keanekaragaman hayati ( gen, jenis, ekosistem ) di indonesia.

Materi untuk penelitian ini adalah Keanekaragaman Hayati Indonesia ( gen, jenis, ekosistem), flora, dan fauna.Indikator dalam materi Menyebutkan contoh keanekaragaman hayati indonesia ( gen, jenis, ekosistem), flora, dan fauna.

\section{METODE}

Penelitian ini dilaksanakan pada bulan Juni sampai Oktober Sedangkan lokasi Penelitian yaitu di Kawasan Taman Nasional Gunung Merbabu kecamatan Selo, Kabupaten Boyolali.

Jenis Penelitian yang dilaksanakan adalah penelitian yang bersifat Reasearch and 
Development, penelitian Reasearch and Development merupakan penelitian yang di gunakan untuk menghasilkan produk tertentu dan menguji keefektifan produk tersebut.

Metode yang di gunakan dalam penelitian ini adalah metode point count dengan melakukan pencatatan jenis burung yang di amati dan terdengar di tiga zona pengamatan. Sementara untuk penentuan titik pengamatan di lakukan dengan menggunakan random sampling dengan radius pengamatan minimal 20 meter ke segala arah dari pengamat. kemudian lama Waktu pengamatan pada setiap titik adalah 20 menit. jika sample yang di temukan melimpah dan di tambahkan waktunya jika sample yang di temukan sedikit. Pengamatan tidak dilakukan jika terdapat hambatan pada kondisi lingkungan seperti turunnya hujan ataupun kabut yang akan membuat pengamatan tidak optimal. Kemudian setiap jenis yang terlihat diamati dan dieskripsikan morfologinya, serta di ambil kamera jika memungkinkan. Sedangkan suara yang terdengar di rekam dengan menggunakan smartphond dan disimpan. Pengamatan tidak hanya di lakukan pada saat di titik-titik pengamatan saja tetapi juga di perjalanan antar titik. Meski demikian, pencatatan pengamatan burung di lakukan pada saat perjalanan antar titik.

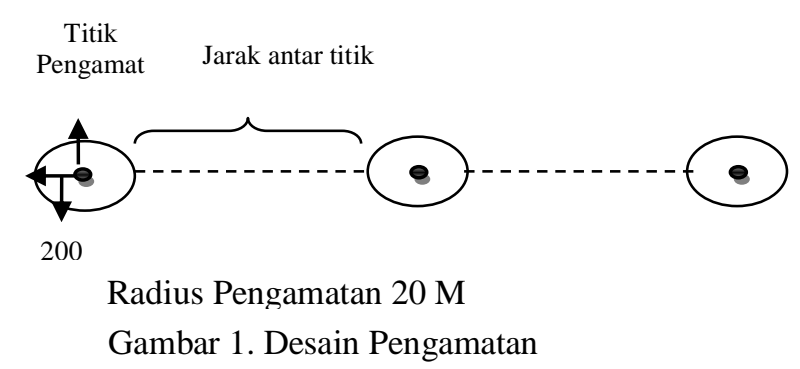

populasi dalam penelitian ini yaitu Seluruh Burung yang termasuk kelas yang

berada di Kawasan Taman Nasional Gunung Merbabu.

Alat dan Bahan yang di gunakan dalam Penelitian . yang pertama adalah Kamera DSLR Nikon d5100 5 jumlah 1 di gunakan untuk memfoto objek burung, Lensa Nikon 70-300mm 1 di gunakan untuk Untuk memokuskan kamera, Binokuler Bushnell 7x $35 \mathrm{~mm}$ di gunakan Untuk memokuskan kamera, Recorder Smartphone untuk merekan suara burung , Buku Panduan Burung-burung di Sumatera, Jawa, Bali, dan Kalimantan - MacKinnon dkk. (2010) sebagai buku panduan lapangan identifikasi, Alat Tulis Buku Catatan, Ballpoint, dan Pensil di gunakan untuk mencatat pengamatan.

Tahap-tahap pengembangan powerpoint berbasis multimedia interaktif sebagai berikut: (1) Perencanaan pembuatan produk tahap perencanaan ini meliputi persiapan alat dan bahan-bahan yang diperlukan untuk pembuatan multimedia interaktif. (2) Pembuatan produk diawali dengan pembuatan powerpoint dengan materi, berupa teks, gambar dan grafis yang menarik, kemudian ditambahkan video dengan sound effect dan interaksinya Uji validasi ahli, media pembelajaran diuji validasi ahli yang terdiri dari ahli media pembelajaran dan guru biologi (praktisi). Uji validasi dilakukan dengan (3) Ada dua instrumen penilaian validasi yaitu oleh guru biologi dan ahli media. Berikut adalah langkah-langkah untuk menganalisis data instrumen penilaian validasi.

Menghitung skor rata-rata

$\mathrm{X}=\frac{1-}{\text { banyak validator }} x \frac{\mathrm{Ex}}{n}$

keterangan:

$\mathrm{x}=$ rata-rata perolehan skor 
$\sum \mathrm{x}=$ jumlah skor yang diperoleh

$\mathrm{N}=$ banyaknya butir pertanyaan.

Tabel 4 Interval Kriteria Penilaian Ahli dan

Mengubah skor rata-rata ke dalam kriteria

kualitatif dengan mengacu pada pedoman

kriteria penilaian

Guru Biologi

Tabel 3.. Kriteria Penilaian Ahli dan Guru

Biologi (Tri Cipto Tunggul Wardoyo, 2015)

\begin{tabular}{lll}
\hline No & Rentang Skor & Kriteria \\
\hline 1 & $\overline{\mathrm{x}}>\mathrm{Mi}+1,5 \mathrm{Sbi}$ & Sangat layak \\
2 & $0<\overline{\mathrm{x}} \leq \mathrm{Mi}+1,5 \mathrm{Sbi}$ & Layak \\
3 & $\mathrm{Mi}-1,5 \mathrm{Sbi}<\overline{\mathrm{x}} \leq 0$ & Kurang layak \\
4 & $\overline{\mathrm{x}} \leq \mathrm{Mi}-1,5 \mathrm{Sbi}$ & Tidak layak \\
\hline
\end{tabular}

\begin{tabular}{lll}
\hline No & Rentang Skor & Kriteria \\
\hline 1 & $\overline{\mathrm{x}}>3,25$ & Sangat layak \\
2 & $2,5<\overline{\mathrm{x}} \leq 3,25$ & Layak \\
3 & $1,75<\overline{\mathrm{x}} \leq 2,5$ & Kurang layak \\
4 & $\overline{\mathrm{x}} \leq 1,75$ & \multicolumn{1}{c}{ Tidak layak } \\
\hline (4)Revisi produk, & Revisi produk awal \\
dilakukan berdasarkan & hasil uji validasi \\
ahli untuk memperbaiki media pembelajaran \\
\multicolumn{2}{l}{ berupa multimedia interaktif. }
\end{tabular}

Keterangan:

Mi $($ mean ideal $)=\frac{1}{2} \times$ skor maksimal ideal + skor minimal ideal.

Sbi (simpangan baku ideal) $=\frac{1}{6} \times$ skor (5)Produk hasil revisi, media pembelajaran berupa multimedia interktif yang layak implementasi.

maksimal ideal - skor minimal ideal Skor

maksimal ideal adalah 4 sedangkan skor minimal ideal adalah 1, selanjutnya interval kriteria penilaian ahli, guru biologi dan siswa dapat diperoleh melalui tabel 4.

\section{HASIL DAN PEMBAHASAN}

Jenis-jenis Aves yang berhasil teramati Tabel 5 Hasil Pengamatan Zona Pemanfaatan Lahan Pertanian dan Pariwisata Ketinggian 1000 - 1400 mdpl.

Berdasarkan tabel pengamatan diketahui bahwa hasil identifikasi aves di Kawasan Taman Nasional Gunung Merbabu terdapat 12 family yang terdiri dari 17 spesies dan 156 individu. 
Hasil identifikasi ini di amati dari 6 titik pengamatan dari 3 zona dengan menggunakan metode point count (perhitungan langsung) dengan rentang waktu 15menit. Untuk zona pemanfaatan pertanian dan pariwisata dengan ketinggian 1000 - 1400 didapatkan 37 individu, Untuk zona Rimba bawah dengan ketinggian 1400 -
Kepudang sungu jawa (Coracina javensis), Sepah gunung (Pericrocotus miniatus), dan Sepah hutan (Pericrocotus spesiosus), Family Columbidae di temukan 3 spesies yaitu dederuk jawa (Streptopelia bitorquata), Tetukur biasa (Spilopelia chinensis), dan Uncal buau (Macropygia emiliana), family Dicrurridae di temukan 1 spesies yaitu

\begin{tabular}{|c|c|c|c|c|c|c|c|}
\hline \multirow{3}{*}{ No } & \multicolumn{2}{|l|}{ Identifikasi } & \multirow{3}{*}{$\begin{array}{c}\text { Nama } \\
\text { Spesies }\end{array}$} & \multirow{2}{*}{\multicolumn{3}{|c|}{$\begin{array}{c}\text { Lokasi Pengamatan } \\
\text { Zona Pemanfaatan dan } \\
\text { Rimba }\end{array}$}} & \multirow[t]{3}{*}{ Jumlah } \\
\hline & \multirow[t]{2}{*}{ Karakternya } & \multirow[t]{2}{*}{ Pola Suara } & & & & & \\
\hline & & & & I & II & III & \\
\hline 1. & $\begin{array}{l}\text { Bertopi hitam, dagu dan kepala atas } \\
\text { hitam, kerah, tunggir, ekor coklat. } \\
\text { Jenis paruh pemakan buah, biji-bijian } \\
\text { serangga. }\end{array}$ & $\begin{array}{l}\text { Chook-chook } \\
\text {, chang-koor } \\
\text { Secara berulang-ulang }\end{array}$ & $\begin{array}{l}\text { Cucak Kutilang } \\
\text { (Pycnonotus } \\
\text { aurigaster) }\end{array}$ & 15 & 17 & 17 & 49 Individu \\
\hline 2. & $\begin{array}{l}\text { Dahi, topeng, dan ekor hitam. Sayap } \\
\text { hitam dengan bintik putih. Mahkota } \\
\text { dan tengkuk abu-abu agak gelap. } \\
\text { Punggung, tunggir, dan sisi tubuh } \\
\text { coklat kemerahan. Jenis paruh } \\
\text { pemakan serangga. }\end{array}$ & $\begin{array}{l}\text { Ciutanya parau, "terrr, } \\
\text { terr", "to-wit" yang } \\
\text { nyaring, serak dan } \\
\text { kicauan merdu. }\end{array}$ & $\begin{array}{l}\text { Bentet Kelabu } \\
\text { (Lanius schach) }\end{array}$ & 9 & 9 & 10 & 38 Individu \\
\hline 3. & $\begin{array}{l}\text { Berwarna kemerahan bagian dada } \\
\text { sampai ke ekor, bulu bagian } \\
\text { mahkota, hitam, paruh hitam. Jenis } \\
\text { paruh pemakan serangga. }\end{array}$ & $\begin{array}{l}\text { "cii-cii-cii”, "tsrii-ii”" } \\
\text { Pada saat bertengger. }\end{array}$ & $\begin{array}{l}\text { Sepah Gunung } \\
\text { (Pericrocotus } \\
\text { miniatus) }\end{array}$ & 2 & 3 & 4 & 9 Individu \\
\hline 4. & $\begin{array}{l}\text { Bulu sayap lebih gelap daripada } \\
\text { bulu tubuh, berwarna abu-abu tua di } \\
\text { bagian sayap dan abu-abu muda di } \\
\text { bagian tubuhnya. Terdapat garis- } \\
\text { garis hitam khas pada leher dan } \\
\text { terdapat bintik-bintik putih halus. } \\
\text { Jenis paruh pemakan biji-bijian. }\end{array}$ & $\begin{array}{l}\text { "te-ku-kurr" nada } \\
\text { terakhir memanjang. }\end{array}$ & $\begin{array}{l}\text { Tekukur Biasa } \\
\text { (Spilopelia } \\
\text { chinensis) }\end{array}$ & 5 & 3 & 4 & 12 Individu \\
\hline 5. & $\begin{array}{l}\text { Warna kepala lebih abu - abu, } \\
\text { bercak hitam pada sisi leher bertepi } \\
\text { putih, tidak berbintik putih. Jenis } \\
\text { paruh pemakan biji-bijian. }\end{array}$ & $\begin{array}{l}\text { "kru - kruuuu", } \\
\text { variasinya adalah } \\
\text { "Dah. ." }\end{array}$ & $\begin{array}{l}\text { Dederuk jawa } \\
\text { (Spilopelia } \\
\text { bitorquata) }\end{array}$ & 1 & 2 & 8 & 11 Individu \\
\hline 6. & $\begin{array}{l}\text { Ekor panjang dengan alis mata } \\
\text { mencolok, paruh kuning panjang } \\
\text { melengkung, sayap dan ekor coklat. } \\
\text { Penutup tubuh warna merah karat. } \\
\text { Jenis paruh pemakan serangga. }\end{array}$ & $\begin{array}{l}\text { "tur-du-du-du-wiit- } \\
\text { wiit" siulan yang di } \\
\text { ulang "pu-pu-ri-uw", } \\
\text { "piow-pu-pu", to- } \\
\text { whiit" }\end{array}$ & $\begin{array}{l}\text { Cica kopi } \\
\text { melayu } \\
\text { (Pomantorhinus } \\
\text { momantus })\end{array}$ & & & 3 & 3 Individu \\
\hline
\end{tabular}

1600 mdpl di dapatkan 48 individu, dan srigunting kelabu (Dicrurus leucophaeus), Untuk zona rimba tengah dengan ketinggian family Laniidae di temukan 1 spesies yaitu 1600 - 1800 di dapatkan 71 individu.

Bentet kelabu (Lanius schach), family Adapun hasil dari identifikasi aves Locustellidae di temukan 1 spesies yaitu Cica di Kawasan Taman Nasional Gunung koreng jawa (Megalurus pallustris), family Merbabu ditemukan 12 family dan 17 Muscicapidae di temukan 2 spesies yaitu spesies. Identifikasi aves yang di dapat pada Ciung batu kecil sunda (Myophonus family Accipitridae ditemukan 1 spesies yaitu glaucinus) dan Sikatan belang (Ficedula Elang hitam (Ictinaetus malaiensis), family westermanni), family Pycnonotidae di Artamidae di temukan 1 spesies yaitu Kekep temukan 1 spesies yaitu Cucak kutilang babi (Artamus leucorynchus), family (Pycnonotus aurigaster), family Sturnidae di Campephagidae ditemukan 3 spesies yaitu temukan 1 spesies yaitu Kerak kerbau 
(Acridotheres javanicus), family Timaliidae di temukan 1 spesies yaitu Cica kopi melayu (Pomatorhinus montanus), dan

family Turdidae di temukan 1 spesies yaitu Anis gunung (Turdus poliocephalus).

Dari hasil penelitian pada zona pertama dengan ketinggian $1000-1400$ mdpl di temukan 7 family, 8 spesies, dan 36 individu. Jumlah individu pada zona pertama lebih rendah di karenakan vegetasi tanaman pada zona ini masih rendah berupa ladang pertanian dan dekat dengan pemukiman serta tempat wisata. jenis tanaman pada zona ini adalah tanaman sayur, seperti kubis, wortel, brokoli, dan kembang kol, sedangkan untuk tanaman kerasnya berupa pinus yang berada di zona pemanfaatan II . adapun populasi burung terbanyak pada zona pemanfaatan adalah burung insektifora yaitu burung pemakan serangga, adapun serangga yang terdapat pada zona ini adalah jenis serangga orthoptera seperti belalang dan lepidoptera yaitu ulat yang masih pada tahapan larva pada kupu-kupu. Hasil ini sesuai dengan pendapat Fredy lala (2013) yang menyatakan bahwa serangga ordo orthoptera adalah kelompok utama yang dimangsa oleh lebih dari seratus spesies burung disamping ordo lepidhoptera dan coleoptera. Faktor yang menyebabkan kelompok serangga ini disukai oleh burung insektifora diduga karena tersedia dalam jumlah relatif banyak, ukuran tubuh yang mudah di lihat, dan relatif mudah di serang .

Hasil penelitian pada zona 2 yaitu zona rimba bawah dengan ketinggian 1400 1600 mdpl di temukan 8 family, 9 spesies, dan 48 individu. pada zona ini di temukan jumlah yang lebih banyak dari pada zona pertama di karenakan pada zona ini merupakan tempat yang cocok untuk berkembang biak dan bertahan hidup.

Pada zona ini jenis tanaman berupa tipe tutupan vegetasi berupa pinus, bintamin, bunga puspa dan jenis - jenis rumput/alang alang yang berada di kawasan ini. Adapun populasi burung yang berada di kawasan ini adalah burung pemakan biji - bijian dan serangga, adapun serangga yang paling banyak di zona ini adalah semut, belalang, jangkrik, ulat. Sedangkan untuk tanaman berbijinya ada pohon bintamin, pinus, puspa dan jenis tumbuhan bawah penghasil biji adalah meniran, mubei. Kebanyakan burung pemakan biji dan buah sumber pakan terdapat pada tanaman meniran dan murbei, sedangkan untuk tepat membuat sarang dan bertengger biasanya pada pohon bintamin dan pinus merupakan tempat berkembangbiak. Hasil ini sesuai dengan pendapat (Wanda Kuswanda, 2010). Faktor penyebaran populasi burung di pengaruhi oleh berbagai tipe hutan, seperti hutan primer, hutan sekunder maupun lahan terbuka/semak belukar merupakan habitat bagi beragam jenis burung. Beberapa jenis burung bahkan menggunakan berbagai tipe habitat tersebut untuk mencari makan, reproduksi, dan menjaga kelangsungan hidupnya. Dalam habitatnya, burung memanfaatkan berbagai jenis tumbuhan sebagai sumber pakan, tempat sarang serta tempat berlindung secara fisiologis .

Hasil penelitian untuk zona 3 yaitu zona rimba tengah di temukan 8 family, 13 spesies dan 71 individu. pada zona ini di temukan lebih banyak burung di bandingkan pada zona 1 dan zona 2 di karenakan pada zona ini merupakan tempat habitat burung dan dekat dengan zona inti. Sehingga populasi burung sangat melimpah. Pada zona 
ini tutupan vegetasi berupa hutan campuran berbagai jenis pohon dan tumbuhan bawah, serta jenis rumput - rumputan /alang - alang. Jenis - jenis pohon yang mendominasi yaitu kesowo (Engelhardia serrata), pampung (Macropanax dispermus), krembi/waru gunung (Homalanthus gegantheus), pasang (Quercus spicata), dan wilodo (Ficus fistulosa). Jenis tumbuhan bawah meliputi kerinyu (Eupatorium inulifolium), kerisan, sengganen, pakisan, cakar ayam, meniran, rumput blabakan, alang - alang murbei. Hasil ini sesuai dengan pendapat Menurut Kwok dan Corlett (2000) Beragam jenis burung sering ditemukan atau melimpah pada tipe hutan primer sub pegunungan, terutama di zona inti karena secara rata-rata memiliki kerapatan tumbuhan (pohon, belta, semai, dan tumbuhan bawah) tertinggi, yaitu sebesar 28.942,5 individu/ha dibandingkan dengan tipe habitat lainnya. kawasan hutan meskipun berupa hutan sekunder merupakan habitat yang lebih baik bagi burung dibandingkan kawasan terdegradasi atau lahan perkebunan. Keragaman jenis burung dapat dipengaruhi oleh kompleksitas tumbuh-tumbuhan pada suatu habitat.

Sedangkan tumbuhan penghasil pakan adalah murbei dan sejenis meniran yang paling banyak. Sedangakan untuk pemakan serangga atau insektifora adalah pohon murbei yang terdapat semut pudak. Kebanyakan burung yang terdapat di kawasan taman nasional gunung merbabu adalah jenis burung pemakan serangga. sehingga penutup vegetasi pada zona ini banyak terdapat rumput - rumputan sehingga populasi serangga meninggat. Hal ini menunjukkan bahwa kondisi vegetasi, baik dominan maupun beragam dapat mempengaruhi pertumbuhan dan perkembangan serangga dan burung. Hasil ini sesuai dengan pendapat fredy lala (2013) Tingkat keanekaragaman tumbuhan yang tinggi menunjukkan bahwa terdapat beragam sumber makanan yang tersedia bagi serangga. Hal ini akan menopang pertumbuhan dan perkembangbiakan serangga dan sehingga dapat meningkatkan populasi dan keanekaragamannya. Kondisi tersebut sangat menguntungkan bagi burung karena memiliki sumber makanan yang banyak dan beragam.

\section{Media Pembelajaran Multimedia Interaktif}

Ahli Media Validasi ahli media dilakukan oleh Prof. Dr. Suwarto, M.Pd. Beliau adalah dosen Pendidikan Biologi Universitas Veteran Bangun Nusantara Sukoharjo. Beliau memberikan beberapa masukan sebagai revisi dari media pembelajaran yang diujikan, yaitu materi di kurangi serta peningkatan kualitas soal dalam pilihan ganda yang sebelumnya c1, c2 di tingkatkan menjadi c5, c6.

Ahli Materi

Validasi ahli materi dilakukan oleh Dra. Tri Wiharti, M. Si. Beliau adalah Kepala Program studi Pendidikan Biologi Universitas Veteran Bangun Nusantara Sukoharjo. Beliau memberikan beberapa masukan sebagai revisi dari media pembelajaran yang diujikan, antara lain penambahan sumber/literatur pada identifikasi dan klasifikasi.

Praktisi/Guru Biologi

Validasi ahli materi dilakukan oleh Samsudin, S.Pd. Beliau adalah Guru Biologi di SMA Negeri 1 Cepogo. Beliau engapresiasi adanya solusi dari pembelajaran biologi yang sebelumnya kurang menarik siswa. 


\section{KESIMPULAN}

Hasil identifikasi di Taman Nasional Gunung Merbabu Kabupaten Boyolali di peroleh data, bahwa di Taman Nasional Gunung Merbabu tersebut peneliti menemukan 12 family, 17 spesies burung, serta 154 individu

Produk media pembelajaran multimedia interaktif hasil identifikasi Aves di Taman Nasional Gunung Mebabu Kabupaten Boyolali untuk siswa SMA/MA kelas $\mathrm{X}$ pada pokok bahasan Keanekaragaman Hayati telah berhasil disusun. Karakteristik proses pengembangan multimedia interaktif meliputi tahap Planning (perencanaan), Design (penyusunan draf, sistematika penulisan dan alat evaluasi), Development (Pengembangan, penulisan, penyuntingan, dan hasil revisi media multimedia interaktif). Karakteristik produk pengembangan media pembelajaran multimedia interaktif yang terdiri dari: halaman judul, petunjuk penggunaan, CV penulis, materi Keanekaragaman Hayati, gambar, video, kuis interaktif, dan hasil identifikasi Aves di Taman Nasional Gunung Merbabu kabupaten Boyolali dan Penutup.

\section{UCAPAN TERIMAKASIH}

Penelitian ini dapat selesai dengan baik karena bantuan dari berbagai pihak. Oleh karena itu penulis mengucapkan terima kasih kepada TNGMb kabupaten Boyolali yang telah banyak membantu.

\section{DAFTAR PUSTAKA}

Ali, Mukhson. Pengembangan Multimedia Pembelajaran Untuk Mata Pelajaran Biologi di SMA: Jurnal Ilmiah Guru "Cope", 18(1), 100-102.

Ayat, A. 2011. Burung-burung Agroforest di Sumatera. In: Mardiastuti, A. eds. Bogor, Indonesia. World Agroforestry Centre ICRAF, SEA Regional Office. 112p.

Balai Taman Nasional Gunung Merbabu. 2017. Burung-Burung Di Taman Nasional Gunung Merbabu. Boyolali: DIPA
Burung-Burung Di Taman Nasional Gunung Merbabu. Boyolali: DIPA

Kuswanda, Wanda . 2010. Pengaruh Komposisi Tumbuhan Terhadap Populasi Burung di Taman Nasional Batang Gadis, Sumatera Utara. Sumatra Utara: Balai Penelitian Kehutanan Aek Nauli .

MacKinnon, John., Phillipps, Karen., van Balen, Bas. 2010. Burung-burung di Sumatera, Jawa, Bali, dan Kalimantan. Burung Indonesia: Bogor.

Wahyudi, Jarot. (2019). Potensi Fauna Burung di Area Grid Wilayah Resort Ampel Taman Nasional Gunung Merbabu. Jakarta: KSDAE. (http://www.ksdae.menlhk.go.id/sains/68692019.html. Di akses pada hari jumat, 19 November pukul 12.25).

Wardoyo, Tri Cipto Tunggul. (2015). Pengembangan Media Pembelajaran Berbasis Video Animasi Pada Mata Pelajaran Mekanika Teknik di SMK Negeri 1 Purworejo. Skripsi. Yogyakarta: Universitas Negeri Yogyakarta 